\title{
Assessing Strategic Goal for Creating Public Value at the Al Ittifaq's Islamic Boarding School for Agribusiness in Indonesia
}

\author{
Bagus Hary Prakoso \\ Ph.D. Candidate in Public Administration and Policy \\ University of Indonesia, Jakarta, Indonesia
}

\begin{abstract}
The purpose of this study is to assess the learning process of strategic goals for creating public value in social entrepreneurship practice. The author utilized Soft Systems Methodology (SSM) based Action Research with the category of theoretical research practice to assess Moore's public value scorecard. Al Ittifaq's Islamic Boarding School for Agribusiness (PPAI) located in Bandung District - West Java - Indonesia is selected as a case study. Study results show that conceptually PPAI has not yet fully practiced the strategic goal activities due to its characteristic and capacity. Besides, those are practiced with different weight of contribution, the implicit learning process is dominant during the strategic goal activities. Nevertheless, all activities can be implemented because PPAI is supported by paternalistic leadership that has rigorously internalized of business partnership and patron client relationship. As concluding remarks, paternalistic leadership, business partnership and patron client relationship become driving force of activities in strategic goal component for creating public value.
\end{abstract}

Keywords: creating public value, strategic goal, paternalistic leadership, business partnership, patron client relationship

\section{Introduction}

With 237 million inhabitants, Indonesia is the world's fourth most populous country after China, India, and United States. According to BPS-Statistics Indonesia (BPS), Indonesia faces 5.81 per cent of unemployment rate in February 2015 and 11.22 per cent of poverty rate in March 2015. The higher portion of unemployment is youth. Besides, Indonesia also faces many challenges such as deforestation, undernourishment, food security, etc. Something unbelievable, as an agricultural country, Indonesia still imports agricultural commodities from other countries, in which local agricultural products and food security are economically and politically important for Indonesia. In 2012, agriculture sector accounted for arround 14 per cent of GDP and 35 per cent of employment. In regional issue and in the midst of what some consider the global competitiveness, Indonesia has faced the Asian Economic Community (AEC) since the early 2016. This issue adds a variety of problems. It also affects disadvantaged regions and people with particular challenges and treatments.

Pertaining those issues, entrepreneurship has been selected as one of strategic ways to overcome those problems in Indonesia. At macro level, Indonesia has launched the national programme on entrepreneurship almost a decade ago (President instruction number 04/1995). Since then, there are about 17 ministries promote entrepreneurship in various approaches such as trainings, access to finance, and exhibition, which can be selected autonomously by each ministry. While at messo level, there is a community foundation such as $\mathrm{Al}$ Ittifaq's Islamic Boarding School (PPAI) which is successful enough in implementing social entrepreneurship through agribusiness development [1]

Refering to Dees [2] PPAI's leader is playing the role of change agents in the social sector by adopting a mission to create and sustain social value, recognizing and relentlessly pursuing new opportunities to serve that mission, engaging in a process of continuous innovation, adaptation and learning, acting boldly without being limited by resouces currently in hand, and finally exhibiting a heightened sense of accountability to the constituencies served and for the outcomes created. Even though PPAI has proved its achievements through creating public values, it still has problems related to application of organizational management and strategic management which are standardized and measurable for guidance organization. As noted from interview (April 3, 2014) with male santri (Islamic students), "in here, we directly practiced without guidance from books. The learning step starts from the ustadz (Islamic teachers), and then to the supervisors, and finally to the santri. It 
requires short times for training before entering to the field work. At previous time, we have been targeted for 3 years, but then now we have been added time due to our incompetence." The impact of those situation, in the context of strategic triangle, it will be somewhat difficult to PPAI to provide strategic goal that is substantively valuable [3].

Some conceptual issues of value creation and social entrepreneurship can be traced from Weerawardena and Mort [4] in their proposition stated that social entrepreneurship efforts to realize social value creation through evidences of innovativeness, proactivity, and management. Austin, Stevenson, and Wei-Skillern [5] stated that a social entrepreneur committed to social entrepreneurship practice that signed by social mission through creating social value. While Michael Porter convinced that social entrepreneurship is the way to improve self-confidence and find out trust from all communities in economic systems [6]. Pertaining critical issues of public value creation as stated by Rhodes and Wanna [5] that public value was unclear concept whether based on normative or empirical reason. Secondly, this concept tends to use much for private management model that is lacking in understanding of goal differences and public management accountability to political and democratic framework. Another opinion stated by Morrell [6] that public value framework was not derived from particular research tradition and found still few empirical researches which could support of those claims. In the future research, it requires redefinition of concept and central argument to improve public value through empirical assessment and investigation.

In response to those factual and conceptual problems above, the purpose of this study is to assess the learning process of strategic goals for creating public value in social entrepreneurship practice. The study limits to explore for strategic goal of strategic triangle which address the criteria of newness of case study and methodology.

\section{Research Method}

This study utilizes Soft Systems Methodology (SSM) with the reason as stated by Patel [8] “... the methodology is unique because it enables the analyst to embark on a process of learning about real world situation being investigated, while simultaneously seeking to improve it by analysing the situation ... and suggesting recommendations for further action to improve the problem situation." According to Checkland and Scholes [9], SSM was a cycle stage which consist of seven stages: (1) problem situation considered problematic; (2) problem situation expressed; (3) root definition of relevant purposeful activity; (4) conceptual models of the named in the root definitions; (5) comparison of models and real world; (6) changes systematically desirable, culturally feasible; and (7) action to improve the situation. Al Ittifaq's Islamic Boarding School for Agribusiness (PPAI) located in Bandung District - West Java - Indonesia has been selected as a case study. It is because its mission, goals, activities, and outcomes are relevant to the concept and practice of social entrepreneurship.

\section{Background on Case Study}

The roles of non profit organization (NPO) in creating public value are through three ways: mission accomplishment, cooperation involvement between public and private sector, and assumption of delivery role through mission fulfillment in which NPO can generate outcomes for community [9]. As a non profit organization, PPAI is a community foundation with some objectives [10] namely (1) to encourage entrepreneurial spirit for students and rural community, (2) to develop highly competitive business center, (3) to set up the Islamic micro finance institution, (4) to develop economic and budgeting networks for Islamic boarding schools (pesantren) horizontally and vertically. To achieve the objectives, it has established some supporting institutions such as cooperative, Islamic schools, mosques with their governance structure, agribusiness incubator, and others for social and economic purposes. Then, in creating public value, PPAI undertakes some kinds of collaborations and processes in order to generate some outcomes (Fig. 1). 


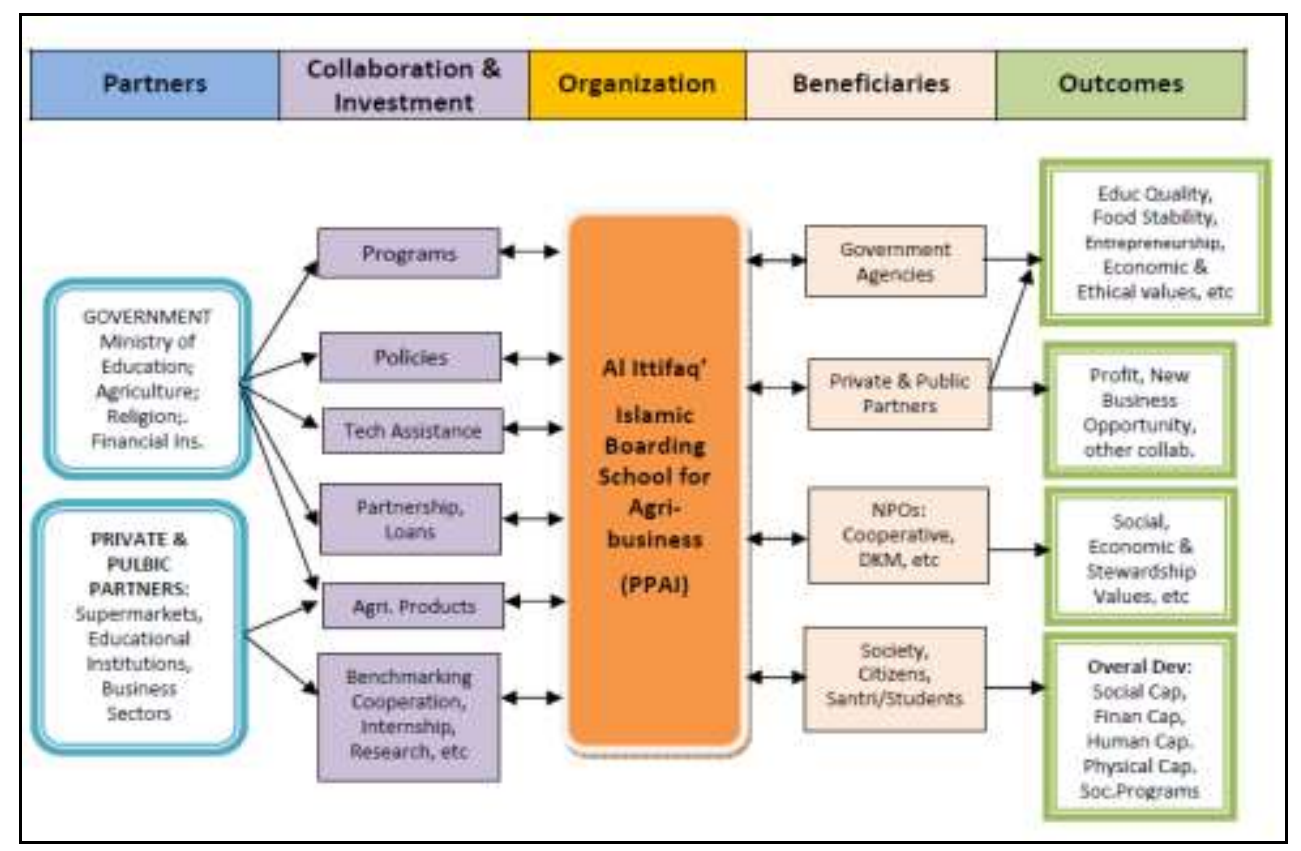

Fig. 1. Value Creation Chain at PPAI

Source: [11]

\section{Result and Discussion}

\subsection{The Stream of Cultural Enquiry}

This stage represents stage 1 and 2, consisting of the intervention of social and political analysis [12]. The purpose of these analysis is to capture the main entities, structure, and viewpoint in the situation, the process going on, the current recognized issues and any potential ones [13]. In social analysis, it focuses on the roles, norms, and values to understand the existence of social reality between PPAI and stakeholders. While in political analysis, it focuses on how power is expressed (see Table I).

TABLE I: Stream Cultural Analysis of PPAI

\begin{tabular}{cl}
\hline \hline \multicolumn{1}{c}{ Analysis } & \multicolumn{1}{c}{ Brief Profile of Social Entrepreneur and Social Enterprise } \\
\hline Social Analysis & $\begin{array}{l}\text { PPAI leader has performed as first and foremost entrepreneur, a passionate advocate, a } \\
\text { dedicated coach and mentor, and a tireless communicator for his students and community. } \\
\text { PPAI has proved its contribution and capacity to develop human capital, improve operational } \\
\text { Pofficiency, create better access to information, create innovative product and service, create a } \\
\text { stable society, and enhance reputation and credibility. }\end{array}$ \\
\hline \hline
\end{tabular}

\section{Source: [14]}

The whole picture of problem situation at these stages is depicted in rich picture (Fig. 2). It is used to "expressing crucial relationships in the situation and most importantly for providing something which could be tabled as a basis for discussion" [15]. 


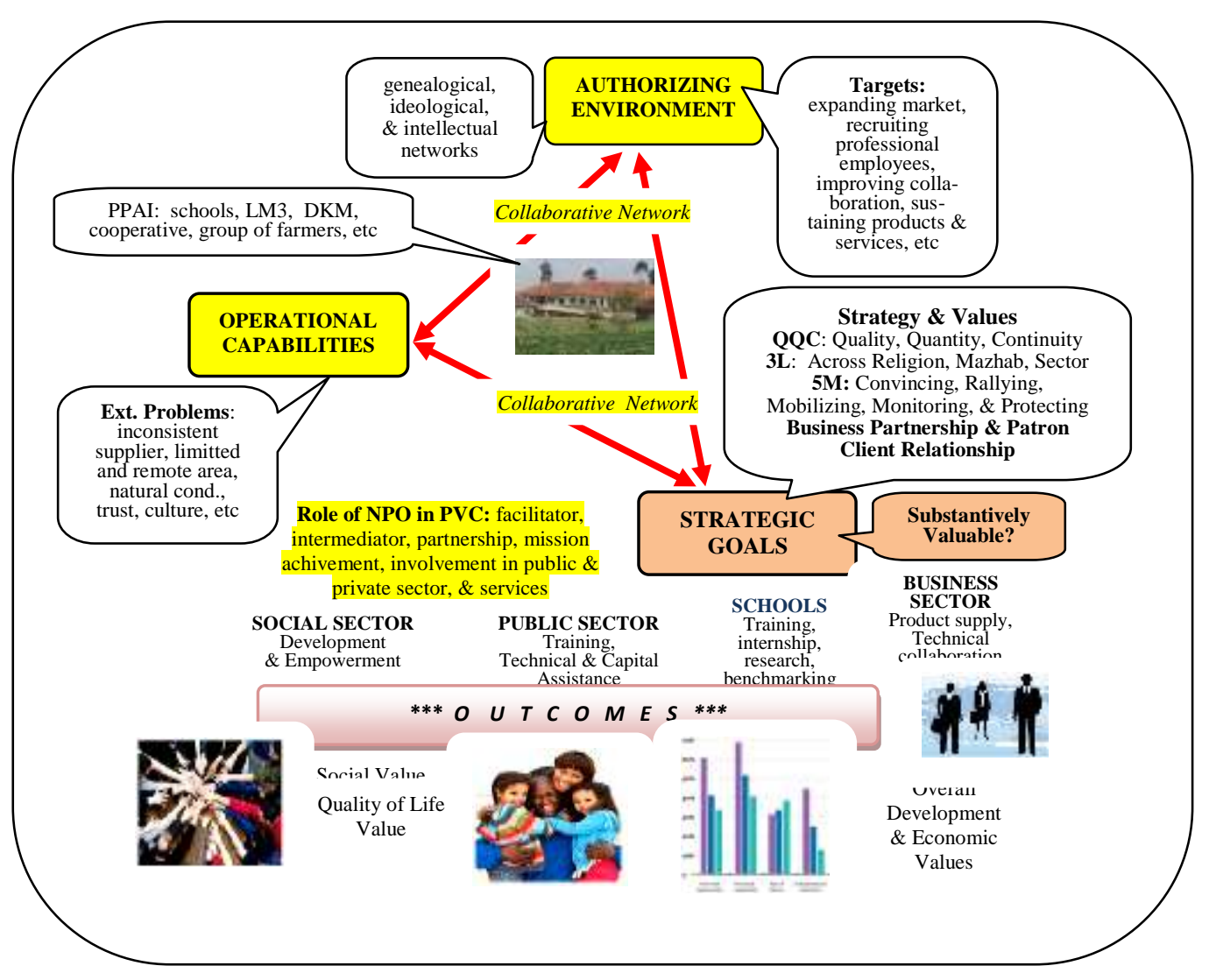

Fig. 2. Rich Picture of Strategic Goal of the Public Value Creation Source: [15]

\subsection{The Stream of Logic-Based Enquiry: Root Definition (RD) and Conceptual Model}

This is a combined stage between stage 3 (root definition of relevant purposeful activity) and stage 4 (conceptual model of the named in the root definition) that provides relevant systems chosen, named, modeled, and compared with perceptions of the real world situation [16]. The aim of this stage is to formulate RD as material to construct conceptual model of which is relevant purposeful human activity systems. RD is a concise description consisting of essential nature of problem situation understanding. A root definition created utilizing CATWOE that must be taken into account with six important elements. The anaysis of CATWOE related to the relevant system to explore strategic goal is as follows: (1) Customer: author and academic advisors, (2) Actor: those who do transformation, (3) Transformation: the proposition of strategic goal that substantively valuable at PPAI, (4) Worldview: the proper exploration and identification of strategic goal at PPAI's management, (5) Owners: those who could stop transformation, (6) Environmental Constraint: time, resources, and realworld. Here is a root definition of strategic goal for PPAI.

"A system which is belonged to and operated by author and academic advisors is to explore strategic goal of the strategic triangle $(P)$, by using $\operatorname{SSM}(Q)$ in order to improve strategic goal that is substanstively valuable at PPAI (R)."

To construct conceptual model, author utilizes Public Value Framework for Accountability and Management Performance [18]. A conceptual model explores the strategic goal consisting of 9 activities as shown in Fig. 3. Checkland and Scholes stated that the models are used as a source of questions to ask of the real world; answering these questions initiates debate, which may be carried out in any way which seems appropriate to the particular situation [19]. 


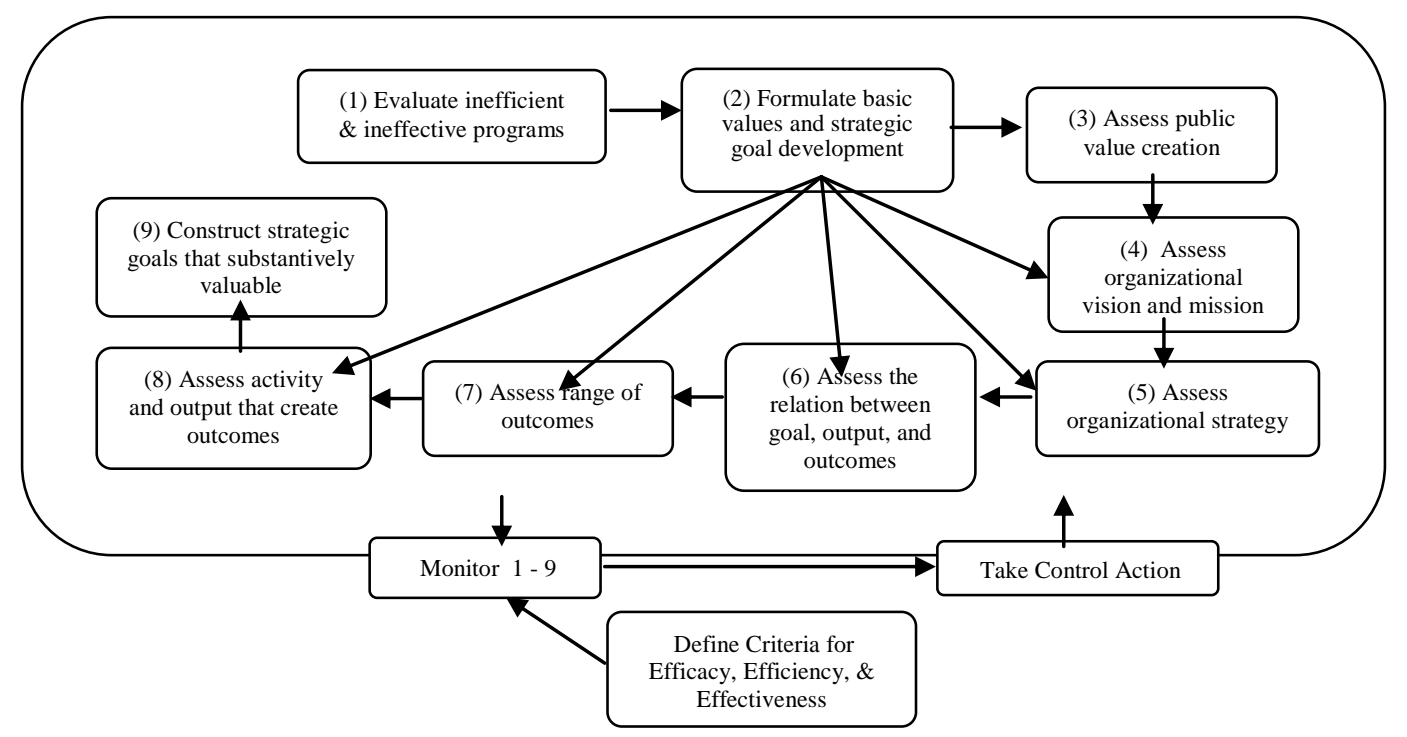

Fig. 3. Conceptual Model of the Strategic Goal Source: Prakoso (2015b)

\subsection{Steps 5 - Comparison of models and real world}

Comparison at this stage is to find how conceptual model compared to real world situation, allowed the author to get a clear picture of the complex situation involving various factors related to strategic goal of public creation to be improved (shown in Table II).

TABLE II: Comparing model with perceived reality

\begin{tabular}{|c|c|c|}
\hline Conceptual Model & Findings & Theoretical Reflection \\
\hline $\begin{array}{l}\text { Evaluating inefficient \& } \\
\text { ineffective programs }\end{array}$ & $\begin{array}{l}\text { Not fully practiced \& unsystematically. } \\
\text { Mostly joined in routine meeting. }\end{array}$ & $\begin{array}{l}\text { Benchmarking consist of vertical and horizontal } \\
\text { process. In horizontal benchmarking is examined } \\
\text { work process across functional area and organization } \\
\text { unit [20]. }\end{array}$ \\
\hline $\begin{array}{l}\text { Formulating basic values } \\
\text { and strategic goal } \\
\text { development }\end{array}$ & $\begin{array}{l}\text { Not fully practiced and implicitly. } \\
\text { Mostly joined in routine meeting. }\end{array}$ & $\begin{array}{l}\text { Kelly, Mulgan, \& Muers [21] stated that public } \\
\text { value create guidance and as holistic approach to } \\
\text { assess performance of public sector. }\end{array}$ \\
\hline $\begin{array}{l}\text { Assessing public value } \\
\text { creation }\end{array}$ & $\begin{array}{l}\text { Not fully practiced \& unsystematically. } \\
\text { Using normative indicators that source } \\
\text { from Islamic tenet and local wisdom, } \\
\text { and leadership role }\end{array}$ & $\begin{array}{l}\text { Incorporate process of cyclical evaluation consisting } \\
\text { of needs assessment/ agenda seeting, task } \\
\text { specification, delivery/implementation, outcomes, } \\
\text { and impacts [22]. }\end{array}$ \\
\hline $\begin{array}{l}\text { Assessing organizational } \\
\text { vision and mission }\end{array}$ & Not fully practiced and implicitly & \multirow{2}{*}{$\begin{array}{l}\text { Creating public value, organization vision and } \\
\text { mission, strategic goals, goal connectivity, output- } \\
\text { outcomes activity, outcomes range, and activity- } \\
\text { outputs that create outcomes [23]. }\end{array}$} \\
\hline $\begin{array}{l}\text { Assessing organizational } \\
\text { strategy }\end{array}$ & Not fully practiced \& unsystematically & \\
\hline $\begin{array}{l}\text { Assessing the relation } \\
\text { between goal, output, } \\
\text { and outcomes }\end{array}$ & Not fully practiced and implicitly & $\begin{array}{l}\text { "Public value management offers distinct new } \\
\text { paradigm and narative reform. It covers redefinition } \\
\text { of how to meet the challenge of efficiency, } \\
\text { accountability, equity, ...." [24]. }\end{array}$ \\
\hline $\begin{array}{l}\text { Assessing range of } \\
\text { outcomes }\end{array}$ & Not fully practiced and implicitly & $\begin{array}{l}\text { Meet the criteria of qualities, services, outcomes, } \\
\text { and trust related to public value implementation by } \\
\text { organization [25]. }\end{array}$ \\
\hline $\begin{array}{l}\text { Assessing activity and } \\
\text { output that create } \\
\text { outcomes }\end{array}$ & Not fully practiced and implicitly & $\begin{array}{l}\text { "Public value can be explained as contribution of the } \\
\text { public sector for social, economic, and } \\
\text { environmental betterment ...." [25]. }\end{array}$ \\
\hline $\begin{array}{l}\text { Constructing strategic } \\
\text { goals that substantively } \\
\text { valuable }\end{array}$ & $\begin{array}{l}\text { Not fully practiced \& unsystematically. } \\
\text { Using normative indicators that sourced } \\
\text { from Islamic tenet \& local wisdom }\end{array}$ & $\begin{array}{l}\text { "Public value provides a comprehensive measure- } \\
\text { ment than that of conventional measurement in the } \\
\text { literature of New Public Management. It consists of } \\
\text { instrument to carry out a such of trust and legitimacy } \\
\text { activities ...." [26]. }\end{array}$ \\
\hline
\end{tabular}

Source: Prakoso (2015b) 
Conceptually, PPAI has not yet fully practiced the function of strategic goal due to its characteristic and capacity. To achieve outcomes through strategic goal, PPAI has utilized some factors of strategic triangle scorecard consisting of organizational vision and mission; strategic goals; links among goals, activities, and outcomes; and actitivities and outputs that create outcomes with different weight of contribution.

In theoretical reflection, public value shapes a guidance and becomes holistic approach to assess the public sector performance through understanding the work process and input-output process that create outcomes. In the context of human activity and problem solving, it commonly inclined to utilize oral and direct communication to the upper leaders. Some problems have been found that PPAI mostly utilized implicit knowledge due to its local culture, lower grade of education in management and teachers, and informal students who come from lower social economic background. It also happens in the learning process which is dominated by the field work rather than theory in the classroom.

Some conceptual model activities can be practiced because PPAI has rigorously internalized of Business Partnership that ultimately become a driving force of activities. During the practice, they are supported by religious values and other strategies as stated by PPAI leader: ".... in here, all people are viewed as brother (partner), why something easy must be made difficult .... we have never told about the race .... a good dancer should follow the musical instrument. That is an Islamic brotherhood ....” (Sept. 5, 2015).

As happened in authorizing environment and operational capability of the strategic triangle, PPAI leader has implemented paternalistic leadership that signed of authoritarianism (authority and power). It shows positive performance development, benevolent capability in protecting, caring, moral, and integrity by delivering virtuous life. The following statement complies with that proposition "... a community does not only need leader but also role model ... have you found me to be an imam (prayer leader)? That was why Mr. Suharto (the second former President of Indonesia) awarded me a Tribute of Tut Wuri Handayani (someone should give moral support and work motivation from the back) ..." (PPAI's leader, Sep. 5, 2015).

\subsection{Stage 6 and 7 - Evaluation of desirability and cultural feasibility of changes, and action to improve the problem situation.}

Refering to conceptual model adopted from Public Value Framework for Accountability and Management Performance in Strategic Goal, the author recommends two other factors to complement that framework (shown in Table III).

TABLE III: Recommendation for Strategic Goal in Public Value Framework

\begin{tabular}{|l|c|l|}
\hline \multicolumn{1}{|c|}{ Factors in Strategic Goal } & \multicolumn{1}{c|}{ Status } & \multicolumn{1}{c|}{ Description } \\
\hline Organizational vision and mission & Still Remained & More explicit \\
\hline Activities and outputs that create outcomes & Still Remained & More explicit \\
\hline Strategic goals & Still Remained & Less explicit \\
\hline Link among goals, activities, output, \& outcomes & Still Remained & Less explicit \\
\hline Range of outcomes & Still Remained & Less explicit \\
\hline $\begin{array}{l}\text { Business Partnership \& Patron Client } \\
\text { Relationship }\end{array}$ & $\begin{array}{c}\text { Addition/ } \\
\text { Improvement }\end{array}$ & $\begin{array}{l}\text { Dominant factors as strategic instrument to } \\
\text { control the achievement. } \\
\text { Providing basic social warranty for subsistence } \\
\text { and security. }\end{array}$ \\
\hline Paternalistic Leadership & $\begin{array}{c}\text { Addition/ } \\
\text { Improvement }\end{array}$ & $\begin{array}{l}\text { Dominant factor as choreographer, social } \\
\text { entrepreneur, mentor, and communicator. }\end{array}$ \\
\hline
\end{tabular}

Source: Prakoso (2015b)

\section{Conclusion}

The learning process of strategic goal for creating public value occurs in ongoing participatory through social entrepreneurship practice. PPAI utilizes more factors of organizational vision and mission, and activities and outputs that create outcomes through agribusiness and religion programs. While the other factors are practiced less explicitly. Of those factors are implemented in the framework of business partnership and patron client relationship, which have been cultivated and supported by PPAI's leader who has strong paternalistic leadership. 


\section{Acknowledgments}

This paper is a part of my Ph.D. dissertation "Public Value Creation in Social Entrepreneurship Practice at the Al Ittifaq's Islamic Boarding School Bandung," by using Soft Systems Methodology based Action Research. The author expresses his utmost gratitude to my Academic Advisors of PDIA-FISIP Universitas Indonesia (Prof. Dr. Martani Huseini as Promotor and Prof. Dr. Sudarsono Hardjosoekarto as Co Promotor). The second utmost gratitude to the Bureau of Planning and Foreign Cooperation - Ministry of Education and Culture Republic of Indonesia which has awarded me a grant-in-aid to undertake oral presentation in International Conference on Studies in Humanities and Social Sciences (SHSS-2016) in Paris - France.

\section{References}

[1] Prakoso, B. H. (2015a). Reconstructing Authorizing Environment of the Public Value Creation in Social Entrepreneurship Practice. American Academic \& Scholarly Research Journal [Online]. Vol 7, No.4. pp. 213-225. Available: http://aasrc.org/aasrj/index.php/aasrj/issue/view/133

[2] Dees, J.G. (1998). Enterprising Nonprofit. Harvard Business Review 76 (1): 12

[3] Moore, M. (1995). Creating Public Value: Strategic Management in Government. Cambridge: Harvard University Press.

[4] Weerawardena, Jay \& Mort, G. S. (2006). Investigating Social Entrepreneurship: A multidimensional Model. Journal of World Business 41 (2006) 21-35).

http://seipa.edu.pl/s/p/artykuly/92/928/Social\%20entrepreneurship\%202006.pdf http://dx.doi.org/10.1016/j.jwb.2005.09.001

[5] Austin, J., Stevenson, H. and Wei-Skillern, J. (2006). Social and Commercial Entrepreneurship: Same, Different or Both? Entrepreneurship Theory and Practice, 30(1): 1-22.

http://dx.doi.org/10.1111/j.1540-6520.2006.00107.x

[6] Porter, M. E. and Kramer, M. R. (2011). Creating Shared Value: How to Reinvent Capitalism and Unleash a Wave of Innovation and Growth. Harvard Business Review. http://businessethics.qwriting.qc.cuny.edu/files/2012/01/PorterKramer.pdf

[7] Rhodes, R. A. W. and Wanna, J. (2007). The Limits to public value, or rescuing responsible government from the Platonic guardians. Australian Journal of Public Administration 66(4): 406-421. http://dx.doi.org/10.1111/j.1467-8500.2007.00553.x

[8] Patel, V. V. (1995). Application of Soft Systems Methodology to the real world process of teaching and learning. International Journal of Education Management. 9 (1), 13-23. http://dx.doi.org/10.1108/09513549510075998

[9] Checkland, Peter., \& Scholes, Jim. (1990). Soft Systems Methodology in Action. England: John Wiley \& Sons Ltd.

[10] Rustandi, Yudi. "Identification of Santri Behavior on Agribusiness Competency Development" (Case study on empowering santri at the Al Ittifaq's Islamic Boarding School for Agribusiness). Thesis, Posgraduate Program Universitas Sebelas Maret, 2010.

[11]Prakoso, B. H. "Public Value Creation in Social Entrepreneurship Practice." Doctoral Dissertation, Department of Administrative Science. FISIP, Universitas Indonesia, 2016.

[12] Checkland, Peter, and Scholes, Jim. (1990). Soft Systems Methodology in Action. England: John Wiley \& Sons Ltd. p. 45

[13]Checkland, Peter, and Poulter, John. (2006). Learning for Action: A Short Definitive Account of Soft Systems Methodology ad its use for Practitioners, Teachers, and Students. England: John Wiley \& Sons Ltd. p. 25

[14] Daly, J. (2000) and (Nelson, J. and Zadek S. Partnership Alchemy. The Copenhagen Center, 2001) in Prakoso (2015b)

[15]Checkland, Peter, and \& Poulter, John. (2006). Learning for Action: A Short Definitive Account of Soft Systems Methodology ad its use for Practitioners, Teachers, and Students. England: John Wiley \& Sons Ltd.

[16]Prakoso, B. H. "Public Value Creation in Social Entrepreneurship Practice." Doctoral Dissertation, Department of Administrative Science. FISIP, Universitas Indonesia, 2016.

[17] Hardjosoekarto, Sudarsono. (2012). Construction of Social Development Index as a Theoretical Research Practice in Action Research by Using Soft Systems Methodology. Syst Pract Action Res (2012) 25:493-509.

http://dx.doi.org/10.1007/s11213-012-9237-9 
[18]Moore, M. (2003). The Public Value Scorecard: A Rejoinder and an Alternative to Strategic Performance Measurement and Management in Non-Profit Organizations. The Kennedy School of Government, Harvard University, Working Paper, pp. 27

www.ksghauser.harvard.edu/PDF_XLS/.../workingpaper_18.pdf )

http://dx.doi.org/10.2139/ssrn.402880

[19] Checkland, Peter, and Scholes, Jim. (1990). Soft Systems Methodology in Action. England: John Wiley \& Sons Ltd. P. 43

[20] Jackson, N. and Lund, H. (2000). Benchmarking for higher education. Society for Research into Higher Education and Open University Press. UK.

[21] Kelly, G., Muers, S., and Mulgan, G. (2002). Creating Public Value: An analytical framework for public service reform. London: Cabinet Office.

http://www.theworkfoundation.com/assets/docs/publications/171_measuring_practical3.pdf

[22] Hills, D., \& Sullivan, F. (2006). Measuring Public Value 2: Practical Approaches. London: the Work Foundation.

[23] Moore, M. H. (2002). The Public Value Scorecard: A Rejoinder and an Alternative Performance Measurement and Management in Non-Profit Organizations by Robert Kaplan, HCNO Working Paper Series.

[24] Stoker, G. (2006). Public Value Management: A New Narrative for Networked Governance? American Review of Public Administration (1): 41-57. http://dx.doi.org/10.1177/0275074005282583

[25] Horner, L., Fauth, R., Mahdon, M. (2007). Creating Public Value: Case Studies. London: The Work Foundation.

[26] Kelly, G., Muers, S., and Mulgan, G. (2002). Creating Public Value: An analytical framework for public service reform. London: Cabinet Office.

http://www.theworkfoundation.com/assets/docs/publications/171_measuring_practical3.pdf

[27] Kelly, G., Muers, S., and Mulgan, G. (2002). Creating Public Value: An analytical framework for public service reform. London: Cabinet Office.

http://www.theworkfoundation.com/assets/docs/publications/171_measuring_practical3.pdf 